\title{
Assessment of Arsenic Distribution in Paddy Soil and Rice Plants of a Typical Karst Basin Affected by Acid Mine Drainage in Southwest China
}

\author{
Chipeng Zhang ${ }^{1}$, Pan $\mathrm{Wu}^{2}$, Changyuan Tang ${ }^{1}$, Zhiwei $\operatorname{Han}^{1} \&$ Jing Sun ${ }^{1}$ \\ ${ }^{1}$ Faculty of Horticulture, Chiba University, Matsudo, Chiba, Japan \\ ${ }^{2}$ College of Resource and Environmental Engineering, Guizhou University, Guiyang 550003, China \\ Correspondence: Changyuan Tang, Faculty of Horticulture, Chiba University, Matsudo, Chiba 271-8510, Japan. \\ Fax: 81-47-308-8911. Tel: 81-47-308-8911. E-mail: cytang@faculty.chiba-u.jp
}

Received: January 18, 2013 Accepted: February 19, 2013 Online Published: March 11, 2013

doi:10.5539/ep.v2n2p27

URL: http://dx.doi.org/10.5539/ep.v2n2p27

\begin{abstract}
The influence of arsenic coal mine on nearby paddy fields was surveyed in Guizhou province, China. The paddy fields were divided into three areas using cluster analysis based on the soil $\mathrm{pH}, \mathrm{Fe}$ and As contents. The average values were $6.5,68.70 \mathrm{~g} / \mathrm{kg}$ and $47.36 \mathrm{mg} / \mathrm{kg}$ in Area I, were $5.2,62.36 \mathrm{~g} / \mathrm{kg}$ and $82.88 \mathrm{mg} / \mathrm{kg}$ in Area II, and were $4.3,78.38 \mathrm{~g} / \mathrm{kg}$ and $121.03 \mathrm{mg} / \mathrm{kg}$ in Area III, respectively. The mobile As contents in Areas II and III were higher than in Area I. The enrichment of As in paddy soil and change of soil properties increased the arsenic concentration in rice plants, where the transfer factor of As from soil to rice grain was about 0.009 . The average As concentrations in Areas I, II and III were 9.58, 21.67 and $25.41 \mathrm{mg} / \mathrm{kg}$ in roots of rice, 2.50, 3.41 and 3.90 $\mathrm{mg} / \mathrm{kg}$ in straw, and $0.42,0.85$ and $1.09 \mathrm{mg} / \mathrm{kg}$ in grain, respectively. It was estimated that the daily intake of total As and inorganic As for a $60 \mathrm{~kg}$ adult through rice consumption were above $4.2 \mu \mathrm{g} / \mathrm{kg}$ body weight/day and above $0.144 \mathrm{mg} /$ day, respectively. The correlation analysis showed that As concentration in rice had a significant positive correlation with soil As concentration $\left(r_{\text {root }}=0.672, p<0.05 ; r_{\text {straw }}=0.725, p<0.01 ; r_{\text {grain }}=0.759, p<\right.$ 0.01), a negative correlation with soil $\mathrm{pH}, \mathrm{K}, \mathrm{Ca}$ and $\mathrm{Mg}$ contents, and a positive correlation with soil organic matter and Fe content.
\end{abstract}

Keywords: paddy field, arsenic, water, rice, health risk

\section{Introduction}

Arsenic is a highly toxic element that has a significant negative impact on human health as a consequence of continued ingestion. The continuous arsenic exposure increases the risk of heart disease, cancer, and chronic lower respiratory disease (Tseng, 2008). Furthermore, low arsenic exposure has previously been reported to increase human risk of diabetes (Navas-Acien, Silbergeld, Pastor-Barriuso, \& Guallar, 2008). The main route of human exposure to arsenic is through ingestion of foods. Rice, a staple food for more than half of the world's population, is more susceptible to arsenic uptake than other cereal crops due to reductive conditions in paddy fields (Williams et al., 2007). The content of arsenic in rice crops normally ranges from 0.08 to $0.20 \mathrm{mg} / \mathrm{kg}$ (Zavala \& Duxbury, 2008). This level might reach $7.5 \mathrm{mg} / \mathrm{kg}$ in rice from heavily contaminated soils (Liao, Chen, Xie, \& Liu, 2005). As a result, the arsenic mobility in paddy soil has become an environmental concern. The arsenic content in soil commonly ranges from 1 to $40 \mathrm{mg} / \mathrm{kg}$ with an average of $5 \mathrm{mg} / \mathrm{kg}$, depending on geology and soil formation (Mandal \& Suzuki, 2002). The natural abundance of arsenic in the soil is above $40 \mathrm{mg} / \mathrm{kg}$ in most of the Xingyi region, a typical high arsenic area in southwest China (Feng, 2007). High arsenic coals have been found in several areas around this region (Ding et al., 2001). Mining activities may further increase the As concentration of soil. Human health may be significantly at risk because of arsenic pollution caused by mining activities in the Xingren county, where the average daily intake of arsenic per person is estimated to be $2.4 \mathrm{mg}$, of which $87.9 \%$ came from food (Sun et al., 2001). It is still uncertain if the content of total arsenic in rice crops is highly correlated to As levels in paddy soil, because arsenic availability for rice uptake is influenced by soil properties such as soil pH, organic matter, iron oxides et al. (Bogdan \& Schenk, 2009; Hsu, Hsi, Huang, Liao, \& Hseu, 2012; Sheppard, 1992).

The mobility, bioavailability and toxicity of arsenic in soil are influenced by arsenic fractions, nd the total 
arsenic content can only give limited information for understanding its biogeochemical cycling in soil. Most of the arsenic was in reducible and residual fractions, combining with the minerals of iron (oxy) hydroxides and sulfide in uncontaminated soils (Bhattacharyya, Tripathy, Kim, K., \& Kim, S., 2008; Nóvoa-Muñoz et al., 2007). In spite of low content of As in natural soil, water-soluble and exchangeable fractions of arsenic are more toxic than other fractions because they are more soluble (Fernández, Sommer, Cram, Rosas, \& Gutiérrez, 2005). However, the arsenic in the soil from anthropogenic sources tends to be more mobile, implying greater potential availability for plant uptake (Taggart et al., 2004). As a result, sequential extraction procedures are usually used to estimate the arsenic fractions in soils.

The behavior of arsenic in paddy field is complex. Arsenic in the soil is mainly bound to iron oxyhydroxides. The reductive dissolution of iron oxyhydroxides causes the arsenic to be mobilized as arsenite in the soil pore water (Inskeep, McDermott, \& Fendorf, 2002; Khan et al., 2010). The decrease of soil pH may enhance the dissolution of arsenic and iron. However, it has also been reported that arsenic uptake by plants may increase in higher $\mathrm{pH}$ soil (Campbell, Stark, \& Carlton-Smith, 1985). The organic matter in soil can enhance or reduce arsenic mobility with the mechanisms of competition for available adsorption sites, complex formation in aqueous, and/or reduction potential changes (Wang \& Mulligan, 2006). However, the relationship between rice arsenic availability and soil condition is still uncertain (Fu et al., 2011; Huang, Gao, Wang, Staunton, \& Wang, 2006).

Atypical watershed influenced by acid mine drainage (AMD) in the Xingren county has been chosen for the present study. The objectives are 1) to survey the spatial distribution characteristics of As in the paddy field; 2) to assess the variation of soil chemical characteristics and controlling factors of arsenic mobility in soil; and 3) to evaluate the transfer of As from the contaminated soil to rice to determine the potential risk to human health.

\section{Material and Methods}

\subsection{Site Descriptions}

The Jiaole watershed is an endemic arsenosis area located in the Xingyi region, southwest China, with a sub-tropical plateau climate and an average annual temperature of $15.2{ }^{\circ} \mathrm{C}$. The average annual rainfall is about $1320.5 \mathrm{~mm}$, of which $84 \%$ occurs during the rainy season from May to October. The bedrock is dominated by sedimentary carbonate rocks from the Permian to Triassic period, mainly composed of gray dolomites, dolomitic lime stones and gray lime stones (Ding et al., 2001). The soil is classified as ferraliccambiso (FAO-UNESCO). Rice is the main crop in the area, and the paddy fields are irrigated by water from the Shitouzhai and Maoshitou reservoirs (Figure 1). Because of inflow of AMD from high arsenic coal mines upstream of the Maoshitou reservoir since the1990s, paddy fields irrigated by this water have been seriously acidified (Tang, Wu, Tao, Zhang, \& Han, 2009). It has been reported that the coal had an arsenic content above $1160 \mathrm{ppm}$ and the main arsenic bearing minerals in the coal were As-rich pyrite and arsenopyrite (Ding et al., 2001).

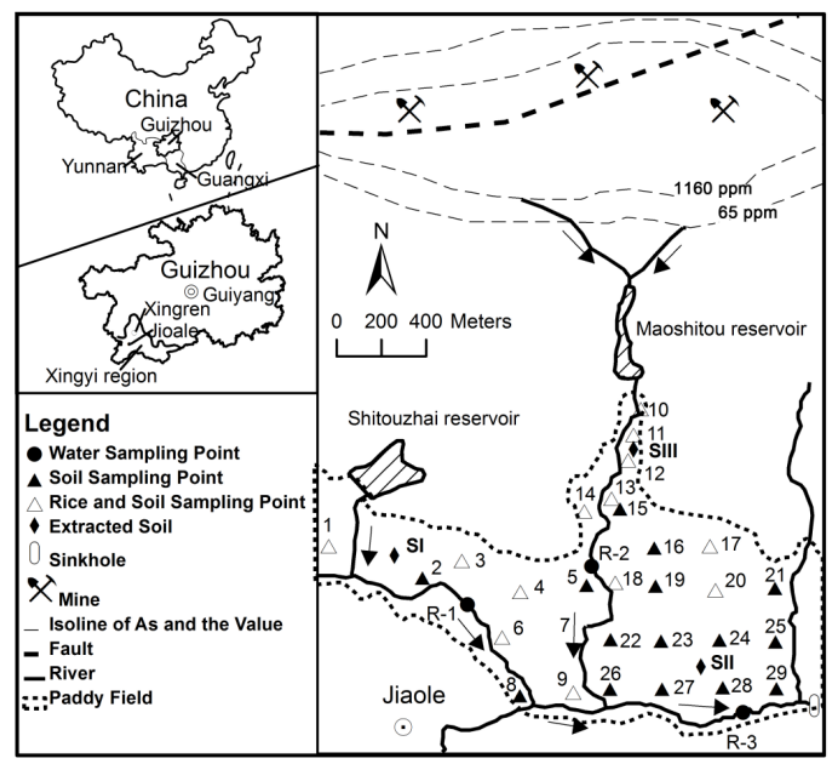

Figure 1. Map of study area and sampling points 


\subsection{Sample Collection and Preparation}

Field surveying was conducted in September 2011. One water samples was collected from the surface of each river (R-1, R-2 and R-3) from which the water was used to irrigate the paddy fields in the watershed (Figure 1). Waters were filled fully into two $50 \mathrm{ml}$ high-density polyethylene tubes after being filtered with $0.45 \mu \mathrm{m}$ Millipore filter (Millipore corp., USA) in situ, one tube for analyzing anions and the other for cations. The tubes were pre-cleaned with nitric acid wash and ultrapure water rinse. The samples for analyzing cations were acidified in situ to $\mathrm{pH}<2.0$ by using hydrochloric acid of analysis grade. All the water samples were stored in the refrigerator at $4{ }^{\circ} \mathrm{C}$ before analysis. Temperature, $\mathrm{pH}$, electrical conductivity (EC), redox potential (Eh) and dissolved oxygen demand (DO) were measured in situ by using portable meters (Multi340i, Germany). Soil samples $(0-25 \mathrm{~cm}$ in depth) were collected from 29 sites from which rice plants were also sampled at 14 sites (Figure 1).

After air-drying for a week at room temperature, soil samples were passed through the standard sieve of 100 mesh $(0.149 \mathrm{~mm})$, and stored in air-sealed polyethylene bags. The soil samples were digested using $\mathrm{HF}, \mathrm{HCl}$ and $\mathrm{HNO}_{3}$ for analysis of $\mathrm{K}, \mathrm{Ca}, \mathrm{Mg}, \mathrm{Fe}, \mathrm{Mn}$, and As. The rice plant samples were washed at the laboratory to remove soil, and oven dried at $70{ }^{\circ} \mathrm{C}$ until a constant weight was obtained. The plants were separated into three parts; root, straw, and rice grain, and then ground in a stainless steel mill. The plant samples were digested using $\mathrm{H}_{2} \mathrm{O}_{2}$, $\mathrm{HF}$ and $\mathrm{HNO}_{3}$ for As analysis.

\subsection{Sequential Extractions}

Sequential extraction procedure (SEP) can give useful information about the defined phase associations and potential mobility of As in the soil. The SEP developed by Wenzel et al. (2001) was used allowing determination ofthe As fractions in paddy soils (SI, SII and SIII). Based on the dissolution strength, five reagents were selected in the method to extract five As fractions as shown in Table 1. The soil to extractant ratio was modified to $1 / 100$ $(0.25 \mathrm{~g}$ soil $+25 \mathrm{ml}$ extractant in $50 \mathrm{ml}$ centrifugation tubes) to ensure that each extractant did not become exhausted (Keon, Swartz, Brabander, Harvey, \& Hemond, 2001). The mixtures were centrifuged at $3000 \mathrm{~g}$ for 10 $\mathrm{min}$, and the supernatant was filtered through $0.45 \mu \mathrm{m}$ Millipore filters into sample vials. The collected samples were stored at $4{ }^{\circ} \mathrm{C}$ before analysis. All extractions were performed in triplicate. The recovery of the whole extraction procedure $(>80 \%)$ was estimated by comparing the sum of the five fractions with a single digestion by strong acids $\left(\mathrm{HCl}+\mathrm{HNO}_{3}+\mathrm{HF}\right)$.

Table 1. Sequential extraction procedure for As

\begin{tabular}{|c|c|c|c|c|}
\hline Fraction & Extractant & $\begin{array}{l}\text { Extraction } \\
\text { conditions }\end{array}$ & Wash step & Fraction extracted \\
\hline$\overline{\text { As-F1 }}$ & $0.05 \mathrm{M}\left(\mathrm{NH}_{4}\right)_{2} \mathrm{SO}_{4}$ & $4 \mathrm{~h}$ shaking, $20^{\circ} \mathrm{C}$ & & non-specifically sorbed As \\
\hline As-F2 & $0.05 \mathrm{M}\left(\mathrm{NH}_{4}\right) \mathrm{H}_{2} \mathrm{PO}_{4}$ & $\begin{array}{l}16 \mathrm{~h} \text { shaking, } \\
20^{\circ} \mathrm{C}\end{array}$ & & specifically sorbed As \\
\hline As-F3 & $\begin{array}{l}0.2 \mathrm{M} \mathrm{NH}_{4^{-}} \\
\text {oxalate buffer, } \mathrm{pH} 3.25\end{array}$ & $\begin{array}{l}4 \mathrm{~h} \text { shaking in } \\
\text { dark, } 20^{\circ} \mathrm{C}\end{array}$ & $\begin{array}{l}0.2 \mathrm{M} \mathrm{NH}_{4} \text {-oxalate, } \\
\text { pH } 3.25,10 \text { min } \\
\text { shaking in the dark }\end{array}$ & $\begin{array}{l}\text { As associated with amorphous } \\
\text { hydrous } \\
\text { oxides of } \mathrm{Fe} \text { and } \mathrm{Al}\end{array}$ \\
\hline As-F4 & $\begin{array}{l}0.2 \mathrm{M} \mathrm{NH}_{4^{-}} \\
\text {oxalate buffer }+0.1 \\
\text { Mascorbic acid, pH } \\
3.25\end{array}$ & $\begin{array}{l}0.5 \mathrm{~h} \text { in a water } \\
\text { basin at } 96 \pm 3{ }^{\circ} \mathrm{C}\end{array}$ & $\begin{array}{l}0.2 \mathrm{M} \mathrm{NH}_{4} \text {-oxalate, } \\
\text { pH } 3.25,10 \text { min } \\
\text { shaking in the dark }\end{array}$ & $\begin{array}{l}\text { As associated with } \\
\text { crystalline } \mathrm{Fe} \text { and } \mathrm{Al} \\
\text { oxyhydroxides }\end{array}$ \\
\hline As-F5 & $\mathrm{HCl}+\mathrm{HNO}_{3}$ & $\begin{array}{l}\text { microwave } \\
\text { digestion }\end{array}$ & & residual As \\
\hline
\end{tabular}

\subsection{Analytical Methods}

All reagents were of analytical-reagent grade. Milli-Q water (Yamato Millipore-filter, WT $101 \mathrm{UV}$ ) was used. The soil $\mathrm{pH}\left(\mathrm{H}_{2} \mathrm{O}\right)$ was measured by $\mathrm{pH}$ meter (Horiba, Japan) in a suspension of $10 \mathrm{~g}$ soil with $50 \mathrm{ml}$ water. Analysis for cations and anions of water samples was performed by using ion chromatography (ICS-90, Dionex Corp., USA). Metal contents were analyzed using inductively coupled plasma atomic emission spectroscopy (ICP-AES). The analysis for total arsenic in soil was carried out using hydride generation atomic absorption spectrophotometry (HG-AAS) (Shimadzu, Japan). Atomization was performed in an air-acetylene flame. The arsenic determination by this system has a detection limit of $0.1 \mu \mathrm{g} / \mathrm{L}$. The organic matter $(\mathrm{OM})$ content in soil 
was determined by using the potassium dichromate heating method (Yeomans \& Bremner, 1988). The available $P$ in soil was estimated by the method of Bray 1 (Bray \& Kurtz, 1945).

\subsection{Statistical Analysis}

In order to assess the long term effects of irrigation practices on arsenic content in the paddy soil, clustering techniques has been used to classify the soil quality based on the chemical properties of paddy soils. Here, all soil samples are hierarchically clustered based on $\mathrm{pH}$ value and total contents of Fe and As. The raw data were standardized before execution of clustering. Measures for the soils are conducted through the group average method and then classified using square distance. Using a criteria value of square distance between 4 and 5 , the 29 samples can be classified into three clusters, Areas I, II and III as shown in dendrogram (Figure 2).

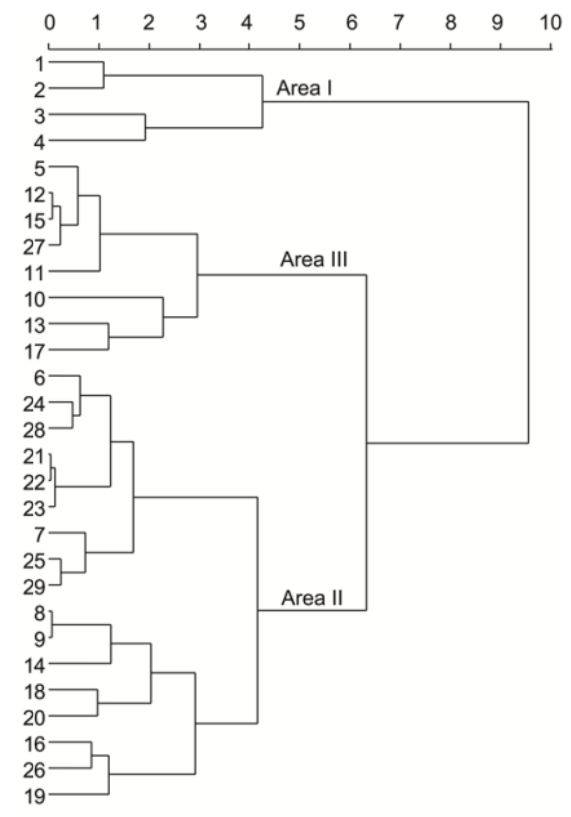

Figure 2. Dendogram from the cluster analysis of the 29 soil samples

Pearson's correlation coefficient was carried out to find out the correlation between arsenic concentrations in different parts of the rice plant and soil properties by SPSS software, version 14.0 for windows (SPSS Inc., Chicago, USA).

\subsection{Estimated Daily Intake (EDI)}

Rice is the main food for the people living in study areas, therefore an EDI of As from rice was determined by the following equation:

$$
E D I=\left(C_{\text {metal }} \times W_{\text {food }}\right) / B_{w}(1)
$$

where $_{\text {metal }}(\mathrm{mg} / \mathrm{kg}), \mathrm{W}_{\text {food }}(\mathrm{kg} /$ day $)$ and $\mathrm{Bw}(\mathrm{kg})$ represent the rice As content, daily average consumption of rice in this region and body weight, respectively. It is reasonably to define the daily average rice consumption for an adult as about $0.6 \mathrm{~kg} / \mathrm{day}(\mathrm{Li}, \mathrm{Feng}, \&$ Qiu, 2010), and the average body weight was considered to be $60 \mathrm{~kg}$ for an adult in the Guizhou province (Zhang, Feng, Larssen, Qiu, \& Vogt, 2010).

\section{Results and Discussion}

\subsection{Irrigation Water}

The waters of R-1, R-2 and R-3 were used for irrigation, and their properties are summarized in Table 2. The water of R-1 was from the Shitouzhai reservoir which is not subjected to the impact of acid mine drainage. It is a type of $\mathrm{Ca}-\mathrm{HCO}_{3}$, being weak alkaline, and met the irrigation water quality standards of China (Ministry of Agriculture of the People's Republic of China, 2005). However, the irrigation water of R-2 was from the Maoshitou reservoir which had been significantly affected by acid mine drainage. Compared with R-1, it had a stronger acidity and higher Fe content. The As content was about $10 \mu \mathrm{g} / \mathrm{L}$, below the WHO irrigation water guideline of $20 \mu \mathrm{g} / \mathrm{L}$. It was still higher than the As concentration of R-1, even although the high As coal mines 
have been forbidden to exploit since 2004. After mixing of the two streams, the water pH of R-3 was about 4.0. Much iron was precipitated on the bottom of the stream, and the sediment was yellow brown.

Table 2. Physical and chemical properties of the irrigation waters in the study area

\begin{tabular}{ccccc}
\hline & & \multicolumn{3}{c}{ Irrigation River } \\
\cline { 3 - 5 } & & $\mathrm{R}-1$ & $\mathrm{R}-2$ & $\mathrm{R}-3$ \\
\hline $\mathrm{Temp}$ & $\left({ }^{\circ} \mathrm{C}\right)$ & 24.5 & 21.9 & 23.2 \\
$\mathrm{pH}$ & & 8.0 & 3.1 & 4.0 \\
$\mathrm{EC}$ & $(\mathrm{dS} / \mathrm{m})$ & 0.4 & 1.6 & 0.7 \\
$\mathrm{DO}$ & $(\mathrm{mg} / \mathrm{L})$ & 8.6 & 4.2 & 6.9 \\
$\mathrm{Eh}$ & $(\mathrm{mv})$ & 181.3 & 551.0 & 482.5 \\
\hline $\mathrm{Na}^{+}$ & & 4.5 & 3.2 & 2.1 \\
$\mathrm{~K}^{+}$ & & 2.8 & 1.9 & 1.7 \\
$\mathrm{Ca}^{2+}$ & & 47.6 & 70.4 & 63.8 \\
$\mathrm{Mg}^{2+}$ & & 12.6 & 13.7 & 12.5 \\
$\mathrm{Cl}^{-}$ & & 6.8 & 1.1 & 0.6 \\
$\mathrm{NO}_{3}{ }^{-}$ & $(\mathrm{mg} / \mathrm{L})$ & 8.6 & 23.7 & 5.8 \\
$\mathrm{SO}_{4}{ }^{2-}$ & & 58.2 & 1337.2 & 418.9 \\
$\mathrm{HCO}_{3}{ }^{-}$ & & 134.2 & $/$ & $/$ \\
$\mathrm{Fe}$ & & 0.7 & 27.3 & 3.7 \\
$\mathrm{Al}$ & & 0.3 & 35.1 & 23.1 \\
$\mathrm{Mn}^{\mathrm{As}}$ & $(\mu \mathrm{g} / \mathrm{L})$ & 6.4 & 10.3 & 8.4 \\
\hline
\end{tabular}

\subsection{Soil Chemical Characteristics and the As Fraction in Different Areas}

The coefficients of variation (C.V.) for the soil pH, Fe, Mn, As, organic matter and available P were above 15\%, indicating a considerable variability in the paddy fields (Table 3 ). Soil $\mathrm{pH}$ varied over a wide range from 3.50 to 7.00, with an average value of 5.10. The soils from sites 1 to 4 (near to the Shitouzhai reservoir) had a higher $\mathrm{pH}$ than the soils from sites 10 to 13 (near to the Maoshitou reservoir). The Fe concentration ranged from 41.54 to $92.54 \mathrm{~g} / \mathrm{kg}$, and was above $80 \mathrm{~g} / \mathrm{kg}$ at sites 10 and 11. The maximum Mn concentration was $1.58 \mathrm{~g} / \mathrm{kg}$, and the concentrations were below $0.2 \mathrm{~g} / \mathrm{kg}$ in some acidified soils. The OM concentration ranged from 12.70 to 71.01 $\mathrm{g} / \mathrm{kg}$ with an average value of $52.96 \mathrm{~g} / \mathrm{kg}$. The concentration of available P ranged from 3.80 to $8.89 \mathrm{mg} / \mathrm{kg}$, and there was a relatively higher concentration from sites 1 to 8 . The arsenic concentration in the paddy soil ranged from 29.05 to $144.30 \mathrm{mg} / \mathrm{kg}$ with an average value of about $89.72 \mathrm{mg} / \mathrm{kg}$. The maximum value was at site 10 . Overall, the acid soils had relatively higher concentrations of $\mathrm{Fe}$ and As and relatively lower concentrations of $\mathrm{Mn}$ and available P. The differences were not significant expect that of $\mathrm{Mn}(\mathrm{p}<0.05)$.

Area I represent the paddy fields irrigated mainly by water from the Shitouzhai reservoir. The average values of $\mathrm{pH}$, total Fe and As of paddy soil were $6.5,68.70 \mathrm{~g} / \mathrm{kg}$ and $47.36 \mathrm{mg} / \mathrm{kg}$, respectively. Area II covers more than half of the paddy fields of the study area. It was irrigated by water which was polluted by AMD. The average values of $\mathrm{pH}$, total $\mathrm{Fe}$ and total As for paddy soil are $5.2,62.36 \mathrm{~g} / \mathrm{kg}$ and $82.88 \mathrm{mg} / \mathrm{kg}$, respectively. Irrigation water used in Area III was significantly affected from the mining activities. Average, paddy soil in Area III had a $\mathrm{pH}$ value of 4.3 and a high content of total Fe $(78.83 \mathrm{~g} / \mathrm{kg})$ and total As $(121.03 \mathrm{mg} / \mathrm{kg})$. Basically, Area I represents background soil values, although the As concentration is above the permissible limit of Chinese environmental quality standard for agriculture soil of $30 \mathrm{mg} / \mathrm{kg}$ (Ministry of Environmental Protection of the People's Republic of China, 1995). The average arsenic content of the surface soil in Areas II and III increased about $75 \%$ and $155.6 \%$ comparing with the Area I. The spatial distribution of arsenic of the three areas is as shown in Figure 3.The high arsenic sites with concentrations above $100 \mathrm{mg} / \mathrm{kg}$ were close to the Maoshitou reservoir and the irrigation rivers (R-2 and R-3). This is because the soil minerals can decrease As mobility through sorption and the slow spread of irrigation water across paddy fields contributes to the settlement of As in the field. 
Table 3. Chemical properties of the soil samples

\begin{tabular}{|c|c|c|c|c|c|c|}
\hline \multirow{2}{*}{ Site } & \multirow{2}{*}{$\mathrm{pH}$} & $\mathrm{Fe}$ & $\mathrm{Mn}$ & $\mathrm{OM}$ & Total As & Available P \\
\hline & & \multicolumn{5}{|c|}{$\mathrm{mg} / \mathrm{kg}$} \\
\hline 1 & 6.3 & 72.37 & 1.31 & 52.78 & 35.00 & 5.42 \\
\hline 2 & 6.1 & 85.89 & 0.43 & 49.12 & 29.05 & 4.71 \\
\hline 3 & 7.0 & 50.21 & 1.58 & 40.23 & 62.78 & 4.90 \\
\hline 4 & 6.4 & 66.34 & 1.15 & 48.34 & 62.60 & 3.99 \\
\hline 5 & 4.6 & 66.51 & 0.18 & 67.05 & 131.12 & 8.89 \\
\hline 6 & 5.3 & 71.50 & 0.81 & 50.86 & 64.20 & 4.75 \\
\hline 7 & 6.0 & 70.29 & 0.78 & 52.24 & 87.24 & 5.25 \\
\hline 8 & 6.1 & 51.55 & 0.25 & 40.20 & 78.38 & 4.71 \\
\hline 9 & 5.9 & 50.07 & 0.25 & 56.70 & 74.33 & 3.25 \\
\hline 10 & 4.4 & 89.79 & 1.13 & 46.19 & 144.30 & 1.09 \\
\hline 11 & 4.4 & 82.90 & 0.50 & 50.37 & 117.72 & 4.42 \\
\hline 12 & 4.3 & 69.10 & 0.20 & 52.61 & 114.36 & 2.90 \\
\hline 13 & 3.5 & 86.00 & 0.24 & 51.01 & 128.49 & 2.57 \\
\hline 14 & 5.9 & 45.68 & 0.34 & 53.46 & 103.39 & 3.09 \\
\hline 15 & 4.5 & 68.89 & 0.13 & 58.08 & 114.82 & 3.19 \\
\hline 16 & 4.6 & 50.92 & 0.12 & 68.90 & 65.59 & 3.61 \\
\hline 17 & 3.7 & 92.54 & 0.32 & 51.92 & 102.98 & 2.90 \\
\hline 18 & 5.4 & 49.25 & 0.30 & 64.96 & 118.19 & 5.04 \\
\hline 19 & 4.8 & 41.54 & 0.10 & 69.18 & 92.90 & 4.33 \\
\hline 20 & 5.3 & 58.24 & 0.92 & 47.37 & 98.77 & 2.90 \\
\hline 21 & 4.5 & 68.19 & 0.10 & 65.14 & 81.47 & 2.85 \\
\hline 22 & 4.6 & 68.12 & 0.19 & 71.01 & 83.73 & 4.76 \\
\hline 23 & 4.6 & 64.56 & 0.25 & 65.14 & 88.28 & 4.33 \\
\hline 24 & 4.7 & 74.35 & 0.10 & 45.00 & 62.08 & 5.76 \\
\hline 25 & 5.2 & 75.19 & 0.23 & 44.16 & 91.31 & 4.07 \\
\hline 26 & 4.5 & 53.15 & 0.27 & 12.70 & 89.91 & 4.14 \\
\hline 27 & 4.5 & 74.91 & 0.26 & 58.57 & 114.41 & 3.80 \\
\hline 28 & 5.0 & 79.45 & 0.30 & 49.74 & 73.78 & 5.04 \\
\hline 29 & 5.6 & 74.91 & 0.43 & 52.82 & 90.75 & 4.33 \\
\hline $\begin{array}{l}\text { C.V. } \\
(\%)\end{array}$ & 16.7 & 20.6 & 88.9 & 21.9 & 30.5 & 33.0 \\
\hline
\end{tabular}

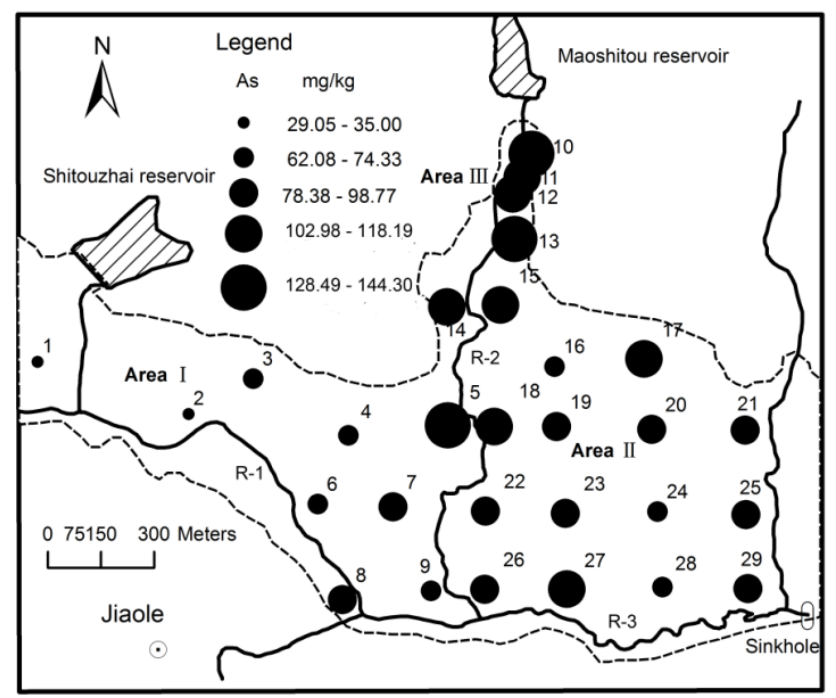

Figure 3. Distribution of arsenic in the paddy fields 
As mobility and potential bioavailability in soil is determined by its binding forms. The results of soil As fractions are shown in Table 4. The contents of non-specifically sorbed As-F1 are low in the soils of three areas, accounting for less than $0.1 \%$ of the total As. The concentration of As-F1 in Area III is highest comparing with other two areas. The increase of As-F1 enhances the toxicity of the paddy soil because they can be easily released into soil water through ion exchange. The content values of specifically adsorbed As-F2 can be released from mineral surfaces through competitive ligand-exchange with $\mathrm{PO}_{4}{ }^{3-}$ (Impellitteri, 2005). The contents of As-F2 in Areas II and III were higher than that of Area I. It is possible that the available As level increases when excessive $\mathrm{P}$ fertilizer is used. By using $\mathrm{NH}_{4}$-oxalate buffer, the As-F3 mainly associated with amorphous $\mathrm{Fe}$ oxyhydroxides in soils was extracted. It was found that the concentration of this form of As in Areas II and III are about 1.8 times higher than that in Area I. This may be related to the increase of the amorphous Fe minerals in the two acidified areas (Table 4). Under the flooding conditions in the paddy field, the reductive dissolution of amorphous iron minerals by organic matter will further increase the bioavailability of As (Bauer \& Blodau, 2006). The total content of As-F1, As-F2 and As-F3 accounts for less than $21 \%$ of the total As in the soils of the three areas. Most of the As exists in the forms of As-F4 and As-F5 which have a stronger stability than the other three mobile forms.

Table 4. The concentrations of amorphous Fe and As fraction in three paddy field soils

\begin{tabular}{ccccccccc}
\hline Soil & $\begin{array}{c}\text { Amorphous Fe } \\
(\mathrm{g} / \mathrm{kg})\end{array}$ & Total As & As-F1 & As-F2 & As-F3 & As-F4 & As-F5 & $\begin{array}{c}\text { Recovery } \\
\%\end{array}$ \\
\cline { 3 - 7 } & 5.05 & 65.28 & 0.05 & 4.04 & 5.72 & 32.77 & 18.46 & 93.5 \\
SI & 7.93 & 82.06 & 0.04 & 6.97 & 10.16 & 37.84 & 11.79 & 81.4 \\
SII & 13.97 & 102.25 & 0.08 & 5.62 & 10.78 & 29.89 & 35.43 & 80.0 \\
SIII & & &
\end{tabular}

SI is Area I; SII is Area II; SIII is Area III.

\subsection{The Estimation of Arsenic in Rice and the Potential Risk to Human Health}

Arsenic content varied in different parts of the rice plants in the order of root $>$ straw $>$ grain. The arsenic contents ranged from 6.35 to $44.70 \mathrm{mg} / \mathrm{kg}$ with an average of $20.58 \mathrm{mg} / \mathrm{kg}$ in root, from 2.21 to $8.95 \mathrm{mg} / \mathrm{kg}$ with an average of $3.76 \mathrm{mg} / \mathrm{kg}$ in straw, and from 0.34 to $1.67 \mathrm{mg} / \mathrm{kg}$ with an average of $0.83 \mathrm{mg} / \mathrm{kg}$ in grain. The As contents in the rice plants from the three areas were different (Table 5). Although the average As contents in root, straw and grain of the rice samples from Area I were the lowest, the As concentration in the grain was higher than the average level of other places in Guizhou province $(0.019 \sim 0.162 \mathrm{mg} / \mathrm{kg}$ ) (Zhu et al., 2008) and even exceeded the Chinese environmental standard for the rice maximum As level which is required to be $0.15 \mathrm{mg} / \mathrm{kg}$ (Chinese Food Standards Agency, 2005). More As was accumulated by the rice planted in Areas II and III. The root As contents were increased to above $20 \mathrm{mg} / \mathrm{kg}$. Following with the increase of As concentration in root, accumulation of As in rice straw and grain were also found. The average ratios of As content in rice straw and root were the highest in Area I. The explanation for this is not clear, however it has been reported that iron oxides formed around the rice root could bind As and reduce its transfer to the above ground tissues (Hartley \& Lepp, 2008; Liu, Zhu, F. Smith, \& S., Smith, 2004). There is no obvious difference of the ratios of As content in rice grain and root in the three areas. Although the root could act as a barrier to intercept the As, the As content of some rice grains in Areas II and III had exceeded the permissible limit of 1 $\mathrm{mg} / \mathrm{kg}$, according to the WHO recommendation (M. A. Rahman, Hasegawa, M. M. Rahman, M. A. Rahman, \& Miah, 2007).

Table 5. As content and ratios in rice root, straw and grain

\begin{tabular}{|c|c|c|c|c|c|c|}
\hline \multirow{2}{*}{ Area } & $\mathrm{As}_{\text {root }}$ & $\mathrm{As}_{\text {straw }}$ & $\mathrm{As}_{\text {grain }}$ & \multirow[b]{2}{*}{$\mathrm{As}_{\text {straw }} / \mathrm{As}_{\mathrm{root}}$} & \multirow[b]{2}{*}{$\mathrm{As}_{\text {grain }} / \mathrm{As}_{\mathrm{root}}$} & \multirow[b]{2}{*}{$\mathrm{As} s_{\text {grain }} / \mathrm{As}_{\text {straw }}$} \\
\hline & & $(\mathrm{mg} / \mathrm{kg})$ & & & & \\
\hline $\mathrm{I}(\mathrm{n}=3)$ & $9.58 \pm 4.04$ & $2.50 \pm 0.38$ & $0.42 \pm$ & $0.29 \pm 0.11$ & $0.05 \pm 0.01$ & $0.17 \pm 0.06$ \\
\hline II $(n=6)$ & $21.67 \pm 10.21$ & $3.41 \pm 1.27$ & $0.85 \pm 0.45$ & $0.18 \pm 0.07$ & $0.04 \pm 0.01$ & $0.26 \pm 0.17$ \\
\hline III $(n=5)$ & $25.41 \pm 11.93$ & $3.90 \pm 0.98$ & $1.09 \pm 0.34$ & $0.17 \pm 0.05$ & $0.05 \pm 0.02$ & $0.29 \pm 0.12$ \\
\hline
\end{tabular}

$\mathrm{n}$ is the number of analysed samples; and the data are presented in mean value and standard deviation. 
As mobility in soil and its uptake by rice is mainly determined by soil properties (Hsu et al., 2012; Lu et al., 2009). The results of correlation analysis are shown in Table 6. Strong negative correlations among soil $\mathrm{pH}$ and arsenic concentrations in rice parts were observed. This may be because the mobilization of As in soil is generally highly $\mathrm{pH}$ dependent. An increased solubility of iron hydroxides at low $\mathrm{pH}$ can lead to a release of iron-bound As from soils to waters. The $\mathrm{pH}$ has a large impact on the redox equilibrium between arsenate and arsenite. For arsenite the maximum adsorption by oxyhydroxides is around $\mathrm{pH} 7$ to 8 . The adsorption will be reduced with the decrease of $\mathrm{pH}$. Therefore, the soil acidification should have promoted the transfer of soil As from soil to rice under flooding condition. The degree of acidification has a close relation with the loss of base minerals $(\mathrm{Ca}, \mathrm{Mg}, \mathrm{K})$ from the soil by leaching. High significant correlations of $\mathrm{K}$ content in soil with arsenic concentration in root $(r=-0.688, p<0.001)$ and grain $(r=-0.668, p<0.001)$ are obtained. Significant correlations between As concentration in straw and $\mathrm{Ca}$ content in soil could also be seen. The arsenic concentrations in rice root, straw and grain had negative correlations with $\mathrm{Mg}$ content in soil. The organic matter might contribute to the As mobility in soil, as there was a positive correlation between As concentration in rice and organic matter content in soil. The paddy soils were rich in organic matter (Table 3). The organic matter in soil can further reduce the adsorption of As. The sorption of humic anions on Fe oxides results in competition for sorption sites and prevents As sorption or induces As desorption, both leading to a stronger mobility in the soil (Wang \& Mulligan, 2006). Although the iron mineral is abundant and it is the main host of As in soil, the correlation between rice As concentration and soil Fe content was positive, but not significant. Significant correlations among arsenic concentration in soil with rice root, straw and grain were observed. In addition, the correlations among As concentrations in rice root, straw and grain were calculated, where significant correlations between As in rice root and straw $(r=0.635, p<0.05)$ and between As concentration in rice root and grain $(r=$ $0.721, \mathrm{p}<0.01)$, were demonstrated.

Table 6. Correlation coefficients (r) between arsenic concentrations in different parts of the rice plant and soil properties

\begin{tabular}{cccccccc}
\hline & $\mathrm{pH}$ & $\mathrm{OM}$ & $\mathrm{K}$ & $\mathrm{Ca}$ & $\mathrm{Mg}$ & $\mathrm{Fe}$ & Total As \\
\hline $\mathrm{As}_{\text {root }}(\mathrm{n}=14)$ & -0.360 & 0.121 & $-0.688^{* *}$ & -0.435 & -0.025 & 0.076 & $0.627^{*}$ \\
$\mathrm{As}_{\text {straw }}(\mathrm{n}=14)$ & -0.237 & 0.118 & -0.436 & $-0.578^{*}$ & -0.119 & 0.139 & $0.725^{* *}$ \\
$\mathrm{As}_{\text {grain }}(\mathrm{n}=14)$ & -0.403 & 0.048 & $-0.668^{* *}$ & -0.320 & -0.428 & 0.088 & $0.759^{* *}$
\end{tabular}

${ }^{* *}$ Correlation is significant at the 0.01 level (2-tailed).

${ }^{*}$ Correlation is significant at the 0.05 level (2-tailed).

The transfer factor (TF) can be used to evaluate the transfer ability of arsenic from soil to rice grain. It is calculated based on the arsenic content in rice grain and total arsenic content in soil $\left(\mathrm{TF}_{\text {total }}=\mathrm{C}_{\mathrm{As} \text {-grain }} / \mathrm{C}_{\mathrm{As} \text {-soil }}\right)$. Table 7 shows some published data of As content in soil and rice grain. It was found that the $\mathrm{TF}_{\text {total }}$ value ranged from 0.006 to 0.074 . The arsenic contents in the soil and rice grain of the study are as were high although the transfer factor $\left(\mathrm{TF}_{\text {total }}\right)$ was low compared with those of other regions. The average value of $\mathrm{TF}_{\text {total }}$ in the paddy fields of study areas was $0.009(\mathrm{n}=14$, range from 0.005 to 0.015$)$.

Based on the data shown in Table 5, the daily intake of total arsenic ranges from about 4.2 to $10.9 \mu \mathrm{g} / \mathrm{kg}$ body weight/day depending on the area where the rice was produced. Arsenic in rice is a threat to human health not only for its high content but also for its speciation. The tolerance value of $0.3 \mu \mathrm{g} / \mathrm{kg}$ body weight $/$ day (equivalent to $0.018 \mathrm{mg} /$ day for a $60 \mathrm{~kg}$ adult) for inorganic As suggested by US Environmental Protection Agency (2009). About 57 to $95 \%$ of the total arsenic in rice are toxic inorganic species in China, and the average $\mathrm{As}_{\mathrm{i}}$ percentage in rice grown on mine impacted soil is about $83 \%$ (Zhu et al., 2008). Supposing that $57 \%$ to $83 \%$ of total arsenic in rice is $A s_{\mathrm{i}}$, the average daily intake of $\mathrm{As}_{\mathrm{i}}$ via rice for adults in the study area was estimated to be $0.144 \sim 0.373$ or $0.209 \sim 0.543 \mathrm{mg} /$ day for a $60 \mathrm{~kg}$ adult. The high levels of arsenic in rice, found in this study, are predicted to significantly impact human health. The higher As concentration in rice straw may also be of concern since the cattle within the study area consumes the straw part of the rice plant. Thus eating the beef as a source of meat may be a further risk of As intake to local population. 
Table 7. A summary of published data of As contents in soil and rice grain

\begin{tabular}{|c|c|c|c|c|}
\hline \multirow{2}{*}{ Country } & \multicolumn{2}{|c|}{ As content $(\mathrm{mg} / \mathrm{kg})$} & \multirow{2}{*}{$\mathrm{TF}_{\text {total }}$} & \multirow{2}{*}{ Reference } \\
\hline & Soil & Rice grain & & \\
\hline \multirow[t]{7}{*}{ China } & 47.36 & 0.42 & 0.009 & Area I \\
\hline & 82.88 & 0.85 & 0.010 & Area II \\
\hline & 121.03 & 1.09 & 0.009 & Area III \\
\hline & 13.70 & 0.191 & 0.014 & (Lu et al., 2010) \\
\hline & 10.20 & 0.295 & 0.029 & (Lu et al., 2010) \\
\hline & 3.0 & 0.092 & 0.031 & (Fu et al., 2011) \\
\hline & $1.29 \sim 25.28$ & $0.041 \sim 0.201$ & $0.006 \sim 0.036$ & (Huang et al., 2006) \\
\hline \multirow[t]{10}{*}{ Bangladesh } & 14.51 & 0.41 & 0.028 & $\begin{array}{l}\text { (M. A. Rahman, Hasegawa, M. M. Rahman, M. A. } \\
\text { Rahman, \& Miah, 2007) }\end{array}$ \\
\hline & 17.0 & 0.270 & 0.016 & (Garnier et al., 2010) \\
\hline & 4.6 & 0.15 & 0.033 & (Garnier et al., 2010) \\
\hline & 5.0 & 0.12 & 0.024 & (Garnier et al., 2010) \\
\hline & 10.4 & 0.58 & 0.056 & (Garnier et al., 2010) \\
\hline & 34.0 & 0.404 & 0.012 & (Stroud et al., 2011) \\
\hline & 11.5 & 0.223 & 0.019 & (Stroud et al., 2011) \\
\hline & 17.4 & 0.572 & 0.033 & (Stroud et al., 2011) \\
\hline & 6.2 & 0.459 & 0.074 & (Stroud et al., 2011) \\
\hline & 23.99 & 0.296 & 0.012 & (Hossain et al., 2008) \\
\hline
\end{tabular}

\section{Conclusions}

Humans living in the Jiaole water shed have a high risk of exposure to As toxicity as a consequence of high As coal exploitation. The irrigation water affected by the AMD has caused soil acidification and enrichment of As and $\mathrm{Fe}$ in the paddy fields. The soil $\mathrm{pH}$ decreased to about 3.5 and As concentration reached around144.30 $\mathrm{mg} / \mathrm{kg}$. The mobilization of As in the paddy fields was inhibited by soil adsorption. The paddy fields close to the contaminated irrigation river had a higher As concentration. The concentrations of mobile forms of As (As-F1, As-F2 and As-F3) in the acidified paddy fields were higher than those in background areas, and they accounted for less than $21 \%$ of the total As content. The soil arsenic had transferred into the rice plant, and the distribution of As in the rice was in the sequence of root > straw > grain. The acidification and As enrichment of the paddy fields had enhanced the transfer of As from soil the rice plants, and the transfer factor of As from soil to rice grain was about 0.009 . The As concentration in rice grain was found to exceed the permissible limit recommended by the WHO. The daily intake of total As and/or inorganic As for local adults through rice consumption was calculated to exceed the human tolerable intake limit.

\section{Acknowledgements}

This research was supported in part by the National Natural Science Foundation of China (No. 40963005), Key Discipline Construction Project of Guizhou University (No. Karst 200902) and the Science and Technology Project of Guizhou Province (No. SY[2009]3059). We thank the members of the Centre of Mining Environmental Engineering and Technology, Guizhou University, for their research assistance. We thank anonymous reviewers for thoroughly reading the paper, providing thoughtful comments.

\section{References}

Bauer, M., \& Blodau, C. (2006). Mobilization of arsenic by dissolved organic matter from iron oxides, soils and sediments. Science of the Total Environment, 354, 179-190. http://dx.doi.org/10.1016/j.scitotenv.2005.01.027

Bhattacharyya, P., Tripathy, S., Kim, K., \& Kim, S. H. (2008). Arsenic fractions and enzyme activities in arsenic-contaminated soils by groundwater irrigation in West Bengal. Ecotoxicology and Environmental 
Safety, 71, 149-156. http://dx.doi.org/10.1016/j.ecoenv.2007.08.015

Bogdan, K., \& Schenk, M. K. (2009). Evaluation of soil characteristics potentially affecting arsenic concentration in paddy rice (Oryza sativa L.). Environmental Pollution, 157, 2617-2621. http://dx.doi.org/10.1016/j.envpol.2009.05.008

Bray, R. H., \& Kurtz, L. T. (1945). Determination of total, organic, and available forms of phosphorus in soils. Soil Science, 59, 39-45. http://dx.doi.org/10.1097/00010694-194501000-00006

Campbell, J. A., Stark, J. H., \& Carlton-Smith, C. H. (1985). International Symposium on Heavy Metals in the Environment, Athens.

Chinese Food Standard Agency. (2005). Hygienic standard for grain-maximum levels of pollutants in rice (GB 2762-2005).

Ding, Z. H., Zheng, B. S., Long, J. P., Belkin, H. E., Finkelman, R. B., Chen, C.G., ... Zhou, Y. S. (2001). Geological and geochemical characteristics of high arsenic coals from endemic arsenosis areas in southwestern Guizhou Province. China. Appl. Geochem., 16, 1353-1360. http://dx.doi.org/10.1016/S0883-2927(01)00049-X

Feng, J. Z. (2007). Guizhou province geochemical atlas. Beijing: Geological Publishing House.

Fernández, P., Sommer, I., Cram, S., Rosas, I., \& Gutiérrez, M. (2005). The influence of water-soluble As(III) and As (V) on dehydrogenase activity in soils affected by mine tailings. Science of the Total Environment, 348, 231-243. http://dx.doi.org/10.1016/j.scitotenv.2004.12.065

Fu, Y., Chen, M., Bi, X., He, Y., Ren, L., Xiang, W., ... Ma, Z. (2011). Occurrence of arsenic in brown rice and its relationship to soil properties from Hainan Island, China. Environmental Pollution, 159, 1757-1762. http://dx.doi.org/10.1016/j.envpol.2011.04.018

Garnier, J. M., Travassac, F., Lenoble, V., Rose, J., Zheng, Y., Hossain, M. S., ... Van Geen, A. (2010). Temporal variations in arsenic uptake by rice plants in Bangladesh: The role of iron plaque in paddy fields irrigated with groundwater. Science of the Total Environment, 408, 4185-4193. http://dx.doi.org/10.1016/j.scitotenv.2010.05.019

Hartley, W., \& Lepp, N. W. (2008). Remediation of arsenic contaminated soils by iron-oxide application, evaluated in terms of plant productivity, arsenic and phytotoxic metal uptake. Science of the Total Environment, 390, 35-44. http://dx.doi.org/10.1016/j.scitotenv.2007.09.021

Hossain, M. B., Jahiruddin, M., Panaullah, G. M., Loeppert, R. H., Islam, M. R., \& Duxbury, J. M. (2008). Spatial variability of arsenic concentration in soils and plants, and its relationship with iron, manganese and phosphorus. Environmental Pollution, 156, 739-744. http://dx.doi.org/10.1016/j.envpol.2008.06.015

Hsu, W. M., Hsi, H. C., Huang, Y. T., Liao, C. S., \& Hseu, Z. Y. (2012). Partitioning of arsenic in soil-crop systems irrigated using groundwater: A case study of rice paddy soils in southwestern Taiwan. Chemosphere, 86, 606-613. http://dx.doi.org/10.1016/j.chemosphere.2011.10.029

Huang, R. Q., Gao, S. F., Wang, W. L., Staunton, S., \& Wang, G. (2006). Soil arsenic availability and the transfer of soil arsenic to crops in suburban areas in Fujian Province, southeast China. Science of the Total Environment, 368, 531-541. http://dx.doi.org/10.1016/j.scitotenv.2006.03.013

Impellitteri, C. A. (2005). Effects of $\mathrm{pH}$ and phosphate on metal distribution with emphasis on As speciation and mobilization in soils from a lead smelting site. Science of the Total Environment, 345, 175-190. http://dx.doi.org/10.1016/j.scitotenv.2004.10.024

Inskeep, W. P., McDermott, T. R., \& Fendorf, S. (2002). Arsenic(V)/(III) cycling in soil and natural waters: chemical and microbiological processes, In W. T. Frankenberger (Ed.), Environmental Chemistry of Arsenic (pp. 183-215). New York: Marcel Dekker.

Keon, N. E., Swartz, C. H., Brabander, D. J., Harvey, C., \& Hemond, H. F. (2001). Validation of an arsenic sequential extraction method for evaluating mobility in sediments. Environ. Sci. Technol., 35, 2778-2784. http://dx.doi.org/10.1021/es001511o

Khan, M. A., Islam, M. R., Panaullah, G. M., Duxbury, J. M., Jahiruddin, M., \& Loeppert, R. H. (2010). Accumulation of Arsenic in soil and rice under wetland condition in Bangladesh. Plant Soil, 333, 263-274. http://dx.doi.org/10.1007/s11104-010-0340-3

Li, P., Feng, X. B., \& Qiu, G. L. (2010). Methlmercury exposure and health effects from rice and fish 
consumption: a review. International Journal of Environmental Research and Public Health, 7, 2666-2691. http://dx.doi.org/10.3390/ijerph7062666

Liao, X. Y., Chen, T. B., Xie, H., \& Liu, Y. R. (2005). Soil As contamination and its risk assessment in areas near the industrial districts of Chenzhou City, Southern China. Environment International, 31, 791-798. http://dx.doi.org/10.1016/j.envint.2005.05.030

Liu, W. J., Zhu, Y. G., Smith, F. A., \& Smith, S. E. (2004). Do phosphorus nutrition and iron plaque alter arsenate (As) uptake by rice seedlings in hydroponic culture? New Phytologist, 162, 481-488. http://dx.doi.org/10.1111/j.1469-8137.2004.01035.x

Lu, Y., Adomako, E. E., Solaiman, A. R. M., Islam, R. M., Deacon, C., Williams, P. N., ... Meharg, A. A. (2009). Baseline soil variation is a major factor in arsenic accumulation in Bengal Delta paddy rice. Environmental Science \& Technology, 43, 1724-1729. http://dx.doi.org/10.1021/es802794w

Lu, Y., Dong, F., Deacon, C., Chen, H. J., Raab, A., \& Meharg, A. A. (2010). Arsenic accumulation and phosphorus status in two rice (Oryza sativa L.) cultivars surveyed from fields in South China. Environmental Pollution, 158, 1536-1541. http://dx.doi.org/10.1016/j.envpol.2009.12.022

Mandal, B. K., \& Suzuki, K. T. (2002). Arsenic round the world: a review. Talanta, 58, 201-235. http://dx.doi.org/10.1016/S0039-9140(02)00268-0

Ministry of Agriculture of the People's Republic of China. (2005). Standard for irrigation water quality (GB 5084-2005).

Ministry of Environmental Protection of the People's Republic of China. (1995). Environmental quality standard for soils (GB 15618-1995).

Navas-Acien, A., Silbergeld, E. K., Pastor-Barriuso, R., \& Guallar, E. (2008). Arsenic exposure and prevalence of type 2 diabetes in US adults. The Journal of the American Medical Association, 300, 814-822. http://dx.doi.org/10.1001/jama.300.7.814

Nóvoa-Muñoz, J. C., Queijeiro, J. M. G., Blanco-Ward, D., Álvarez-Olleros, C., García-Rodeja, E., \& Martínez-Cortizas, A. (2007). Arsenic fractionation in agricultural acid soils from NW Spain using a sequential extraction procedure. Science of the Total Environment, 378, 18-22. http://dx.doi.org/10.1016/j.scitotenv.2007.01.026

Rahman, M. A., Hasegawa, H., Rahman, M. M., Rahman, M. A., \& Miah, M. A. (2007). Accumulation of arsenic in tissues of rice plant (Oryza sativa L.) and its distribution in fractions of rice grain. Chemosphere, 69, 942-948. http://dx.doi.org/10.1016/j.chemosphere.2007.05.044

Sheppard, S. C. (1992). Summary of phytotoxic levels of soil arsenic. Water, Air, and Soil Pollution, 64, 539-550. http://dx.doi.org/10.1007/BF00483364

Stroud, J. L., Norton, G. J., Islam, M. R., Dasgupta, T., White, R. P., Price, A. H., ... Zhao, F. J. (2011). The dynamics of arsenic in four paddy fields in the Bengal delta. Environmental Pollution, 159, 947-953. http://dx.doi.org/10.1016/j.envpol.2010.12.016

Sun, G., Liu, S., Li, B., Li, X., Sun, X., Guo, X., ... Pi, J. (2001). Current situation of endemic arsenicosis in China. Environ. Sciences, 5, 425-434.

Taggart, M. A., Carlisle, M., Pain, D. J., Williams, R., Osborn, D., Joyson, A., \& Meharg, A. A. (2004). The distribution of arsenic in soils affected by the Aznalcollar mine spill, SW Spain. Sci. Total Environ., 323, 137-152. http://dx.doi.org/10.1016/j.scitotenv.2003.10.008

Tang, C., Wu, P., Tao, X., Zhang, C., \& Han, Z. (2009). The basin acidification affected by AMD: A case study in Xingren county, Guizhou, China. Carsologica Sinica, 28, 135-143.

Tseng, C. H. (2008). Cardiovascular disease in arsenic-exposed subjects living in thearseniasis-hyperendemic areas in Taiwan. Atherosclerosis, 199, 12-18. http://dx.doi.org/10.1016/j.atherosclerosis.2008.02.013

US Environmental Protection Agency. (2009). Contaminants in soil:updated collation of toxicological data and intake values for humans.

Wang, S., \& Mulligan, C. N. (2006). Effect of natural organic matter on arsenic release from soils and sediments into groundwater. Environ Geochem Health, 28, 197-214. http://dx.doi.org/10.1007/s10653-005-9032-y

Wenzel, W. W., Kirchbaumer, N., Prohaska, T., Stingeder, G., Lombi, E., \& Adriano, D. C. (2001). Arsenic fractionation in soils using an improved sequential extraction procedure. Analytica Chimica Acta, 436, 
309-323. http://dx.doi.org/10.1016/S0003-2670(01)00924-2

Williams, P. N., Villada, A., Deacon, C., Raab, A., Figuerola, J., Green, A. J., \& Meharg, A. A. (2007). Greatly enhanced arsenic shoot assimilation in rice leads to elevated grain levels compared to wheat and barley. Environ. Sci. Tech., 41, 6854-6859. http://dx.doi.org/10.1021/es070627i

Yeomans, J. C., \& Bremner, J. M. (1988). A rapid and precise method for routine determination of organic carbon in soil. Communications in Soil Science and Plant Analysis, 19, 1467-1476. http://dx.doi.org/10.1080/00103628809368027

Zavala, Y. J., \& Duxbury, J. M. (2008). Arsenic in rice: I. Estimating normal levels of total arsenic in rice grain. Environ. Sci.Technol., 42, 3856-3860. http://dx.doi.org/10.1021/es702747y

Zhang, H., Feng, X. B., Larssen, T., Qiu, G. L., \& Vogt, R. D. (2010). In inland China, rice, rather than fish, is the major pathway for methylmercury exposure. Environ Health Perspect, 118, 1183-1188. http://dx.doi.org/10.1289/ehp.1001915

Zhu, Y. G., Sun, G. X., Lei, M., Teng, M., Liu, Y. X., Chen, N. C., ... Williams, P. N. (2008). High percentage inorganic arsenic content of mining impacted and nonimpacted Chinese rice. Environmental Science \& Technology, 42, 5008-5013. http://dx.doi.org/10.1021/es8001103 